\title{
The Identification of Hexa-, Hepta- and Octoglutamates as the Polyglutamyl Forms of Folate Found throughout the Growth Cycle of Yeast
}

\author{
By R. BASSETT, D. G. WEIR AND J. M. SCOTT \\ Department of Biochemistry, Trinity College, Dublin 2, Ireland \\ (Received I0 March I975; revised I3 October 1975) \\ INTRODUCTION
}

It appears that in all cells the various intracellular folate cofactors are attached to a number of glutamyl residues (Houlihan \& Scott, 1972; Brown, Davidson \& Scott, 1973; Brown et al., 1974) and that many cells contain more than a single polyglutamyl chain length. In fact, of the intracellular folates examined to date only yeast (Pfiffner et al., 1946), Clostridia (Curthoys, Scott \& Rabinowitz, 1972) and T-even phages (Kozloff \& Lute, 1973) have single polyglutamyl forms and in the T-even phages the polyglutamates have a structural rather than a coenzyme role.

To ascertain if yeast synthesizes only the heptaglutamate for the entire growth cycle of the cell, we have re-examined folate polyglutamyl biosynthesis in yeast, using a technique which separates the various polyglutamyl derivatives on previously calibrated ion-exchange columns, after the folates have been cleaved chemically to their corresponding $p$-aminobenzoylpolyglutamyl ( $p$-ABGlu) derivatives (Houlihan'\& Scott, 1972). We found three distinct polyglutamates (the hexa-, hepta- and octo-) throughout the growth cycle; previous reports that only the heptaglutamate is found in yeast appear to be incorrect.

\section{METHODS}

Chemicals. Diethylaminoethyl cellulose (Whatman DE52) was purchased from Ward R. Balston Ltd, Maidstone, Kent, Triton X-I 00 from Koch Light, and the scintillation chemicals 2,5-diphenyloxazole (PPO) and 2,3'-phenylen-bis-(4-methyl-phenyloxazol) (POPOP) from Intertechnique Ltd, Sussex.

Radiochemicals. $p$-Amino- $\left[{ }^{14} \mathrm{COOH}\right]$ benzoate $\left(52 \mathrm{mCi} \mathrm{mmol}^{-1}\right)$ was supplied by Schwartz Mann, Orangeburg, New York, U.S.A. $3^{\prime} 5^{\prime} 9-(\mathrm{n})-\left[{ }^{3} \mathrm{H}\right]$ pteroylglutamate $\left({ }_{5} \mathrm{Ci} \mathrm{mmol}^{-1}\right)$ and pteroylheptaglutamate $\left(\mathrm{PteGlu}_{7}\right)$ in which the terminal glutamic acid was labelled $\mathrm{U}_{-}{ }^{14} \mathrm{C}(\mathrm{I} \cdot 2$ $\mathrm{mCi} \mathrm{mmol}{ }^{-1}$ ) were supplied by the Radiochemical Centre, Amersham, Buckinghamshire.

Radiochemical methods. Radioactivities were determined using a Packard Tri-Carb liquid scintillation spectrometer model 3375. Toluene + Triton X-I00 (2: I w/w) was used with a ratio of I part sample to Io parts scintillation fluid (Turner, I969).

Organisms. Four $p$-aminobenzoate ( $p$-AB)-requiring strains of Saccharomyces cerevisiae were supplied from the culture collection of Arthur Guinness and Son, Dublin, and were designated by them as II 67, I I 85,1288 and 1289 .

Media. The yeasts were maintained as slopes of sabouraud dextrose agar supplied by Oxoid.

Yeast extract was from Difco. All other constituents were Analar-grade reagents supplied by $\mathrm{BDH}$. Three stock salt solutions, A, B and C, were used. Solution A contained $\left(\mathrm{gl}^{-1}\right)$ : $\mathrm{KH}_{2} \mathrm{PO}_{4}, 4.0 ; \mathrm{K}_{2} \mathrm{HPO}_{4}, 0.5 ;\left(\mathrm{NH}_{4}\right)_{2} \mathrm{SO}_{4}, \mathrm{II} \cdot 5 ; \mathrm{NaCl}, 0 . \mathrm{I} ; \mathrm{MgSO}_{4} .7 \mathrm{H}_{2} \mathrm{O}, 0.5 ; \mathrm{CaCl}_{2} .2 \mathrm{H}_{2} \mathrm{O}$, 
$0 \cdot \mathrm{I}$; ferric citrate, $0 \cdot 67$. Solution B contained $\left(\mathrm{g} \mathrm{I}^{-1}\right): \mathrm{CaSO}_{4} \cdot 5 \mathrm{H}_{2} \mathrm{O}, 4 \times \mathrm{I}^{-4} ; \mathrm{KI}, \mathrm{I} \cdot 0 \times \mathrm{I}^{-5}$; $\mathrm{MnSO}_{4} \cdot 4 \mathrm{H}_{2} \mathrm{O}, 2 \cdot 0 \times \mathrm{IO}^{-5}$. Solution $\mathrm{C}$ contained $\left(\mathrm{g} \mathrm{I}^{-1}\right)$ : calcium pantothenate, $\mathrm{I} \cdot 0 \times \mathrm{I}^{-5}$; thiamine, $\mathrm{I} \cdot 0 \times 10^{-5}$; inositol, $2 \cdot 0 \times 10^{-5}$; pyridoxal- $\mathrm{HCl}, \mathrm{I} \cdot 0 \times 10^{-5}$; nicotinic acid, $5 \cdot 0 \times 10^{-4}$. The final medium consisted of $\mathrm{I} 1$ solution A plus $5 \mathrm{ml}$ solution $\mathrm{B}$ and I $\mathrm{ml}$ solution $\mathrm{C}$; to this was added $\mathrm{I} \cdot 98 \mathrm{~g}$ glucose and $0.25 \mathrm{~g}$ yeast extract.

Culture conditions. Inocula were prepared by transfer of a loop of yeast cells from an agar slope to a test tube containing $5 \mathrm{ml}$ of the above medium. After growth at $28{ }^{\circ} \mathrm{C}$ for $24 \mathrm{~h}$ this $5 \mathrm{ml}$ culture was used to inoculate $200 \mathrm{ml}$ medium in a $500 \mathrm{ml}$ Erlenmeyer flask. For the extraction experiments the cells were grown with $25 \mathrm{nCi}$ of $\left[{ }^{14} \mathrm{C}\right] p-\mathrm{AB} / \mathrm{ml}$, giving a concentration of exogenous $p$-AB of $65.9 \mathrm{ng} \mathrm{ml}^{-1}$. Similar concentrations were used in the distribution experiments where $\left[{ }^{14} \mathrm{C}\right] p-\mathrm{AB}$ was used for incorporation studies. The cells were grown in shaken culture at $28{ }^{\circ} \mathrm{C}$ and, unless otherwise stated, for $48 \mathrm{~h}$. After the appropriate time, I $0 \mathrm{ml}$ of culture was removed. The yeast was harvested by centrifugation, washed once with $20 \mathrm{ml}$ of distilled water and extracted (see Results). The extract was diluted to $100 \mathrm{ml}$ with distilled water and applied to the columns.

Oxidation of the extracted folates. The extracted folates were oxidized to the corresponding aminobenzoyl- $\gamma$-L-glutamates by the addition of $4 \mathrm{ml}$ of $2.0 \%(\mathrm{w} / \mathrm{v}) \mathrm{KMnO}_{4} / \mathrm{IO} \mathrm{ml}$ extract (Houlihan \& Scott, 1972). The mixture was adjusted to $\mathrm{pH} 8.5$ with $\mathrm{I} \cdot 0 \mathrm{M}$-tris base. The resulting suspension was kept at room temperature with occasional shaking for $25 \mathrm{~min}$, after which the $\mathrm{pH}$ was adjusted to 4.0 with I $\mathrm{M}-\mathrm{HCl}$. The precipitate was removed by filtration through glass wool and the $\mathrm{pH}$ of the filtrate re-adjusted to $\mathrm{pH} 7.0$ with $1.0 \mathrm{M}$-tris base. The filtrate was diluted to $100 \mathrm{ml}$ with distilled water which always gave a conductivity of less than $3 \mathrm{~m} \Omega^{-1} \mathrm{~cm}^{-1}$.

Chromatography. The oxidized extract was chromatographed on $20 \times 0.7 \mathrm{~cm}$ glass columns containing DEAE-cellulose (Whatman DE52) which had previously been equilibrated with $5 \mathrm{~mm}$-tris- $\mathrm{HCl}$ buffer $\mathrm{pH} 7 \cdot 0$. To each column, $100 \mathrm{ml}$ extract was applied and elution was effected with the non-linear gradient described in Fig. I. The flow was 10 to $15 \mathrm{ml} \mathrm{h}^{-1}$ at $20^{\circ} \mathrm{C}$ and $6.0 \mathrm{ml}$ fractions were collected. Columns were previously calibrated with $p$ aminobenzoylpolyglutamates $\left(p-\mathrm{ABGlu}_{2-7}\right)$ prepared in this laboratory (Houlihan \& Scott, I972).

\section{RESULTS}

All four strains of $S$. cerevisiae grew vigorously on a completely defined medium only when supplemented with $0.025 \%$ yeast extract. Since no increase in growth was observed upon the addition of $p-\mathrm{AB}$ it can be assumed that the yeast extract has sufficient $p$-AB to support optimum growth under the conditions used. However, from the radioactive uptake studies reported in this paper the amount of endogenous $p-\mathrm{AB}$ or other growth factors available in the yeast extract was clearly so small as not to stop accumulation by the organism of the small quantity of radioactive $p$ - $\mathrm{AB}$ added. All four strains, growing in the exponential phase when transferred to fresh medium containing $65.9 \mathrm{ng} \mathrm{ml}^{-1}$ of radioactive $\left[{ }^{14} \mathrm{C}\right] p$ $\mathrm{AB}$, removed more than $80 \%$ of the label from the medium during $18 \mathrm{~h}$ growth. Several methods of extraction of the incorporated folate were examined and it was found that the following procedure usually gave almost total recovery of the incorporated label (70 to $100 \%)$. Wet cells $(0.25 \mathrm{~g})$ were suspended evenly in $25 \mathrm{ml}$ distilled water and lyophilized overnight. The dry cells were suspended in Io ml toluene and kept at $40{ }^{\circ} \mathrm{C}$ for $\mathrm{I} 2 \mathrm{~h}$. To this suspension $100 \mathrm{ml}$ of a $\mathrm{I} \%(\mathrm{w} / \mathrm{v})$ potassium ascorbate solution $\mathrm{pH} 7 \cdot 0$ was added. After shaking and standing, the aqueous layer was centrifuged and the supernatant containing the extracted folates was removed. After extraction, the incorporated label must 


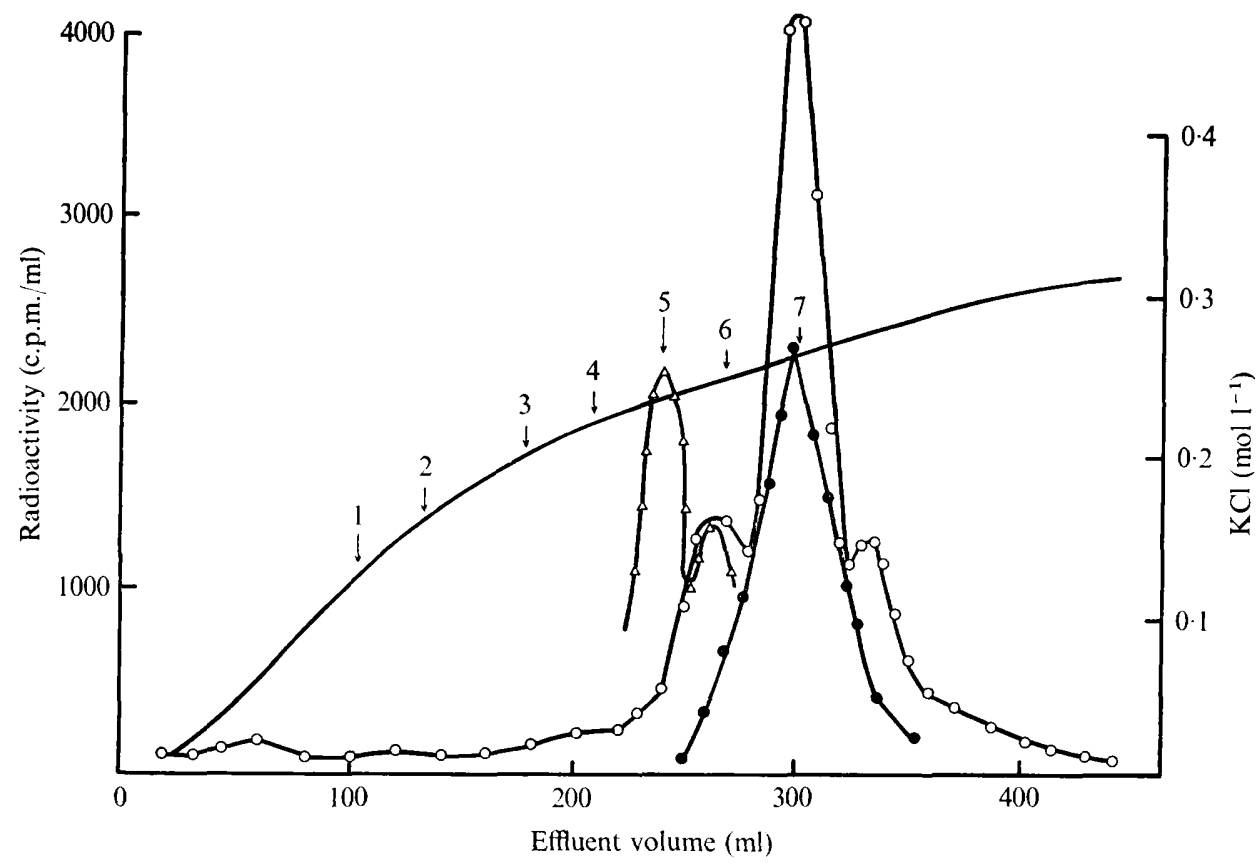

Fig. I. DEAE-cellulose chromatography of $p$-amino- $\left[{ }^{14} \mathrm{C}\right]$ benzoylpoly- $\gamma$-L-glutamate derivatives obtained by alkaline $\mathrm{KMnO}_{4}$ oxidation of native folates from a p-AB-requiring strain (I288) of $S$. cerevisiae grown on $p$-amino- $\left[{ }^{14} \mathrm{COOH}\right]$ benzoate $(O)$. Standards, either $p$-ABGlu $(\bullet)$ or a mixture of $p$-ABGlu - $_{5}$ and $p$-ABGlu $(\triangle)$, were used to calibrate similar columns. Numerals are used to indicate the elution position of these and other standards (i.e. $p$-ABGlu, where $x=0,1 \ldots 7)$. The non-linear gradient shown was constructed by introducing $235 \mathrm{ml}$ of $1 \cdot 0 \mathrm{M}-$ $\mathrm{KCl}$ in $5 \mathrm{~mm}$-tris buffer $\mathrm{pH} 7.0$ from a cylindrical flask $(14 \times 4.5 \mathrm{~cm})$ into a spherical mixing chamber containing $550 \mathrm{ml}$ of $5 \mathrm{~mm}$-tris buffer $\mathrm{pH} 7.0$.

have been in an intact folate polyglutamate, because all of the radioactivity eluted late on Whatman DE52 and, after conjugase treatment, only this area was active for microbiological assay with Lactobacillus casei. Permanganate oxidation resulted in earlier elution from the column, primarily as a p-aminobenzoylheptaglutamate with one larger and one smaller derivative also present (Fig. 1). The identity of the main derivative was established by rechromatographing it with authentic $\left[{ }^{14} \mathrm{C}\right] p$-ABGlu ${ }_{7}$ chemically prepared from $\left[{ }^{14} \mathrm{C}\right] \mathrm{PteGlu}_{7}$ by permanganate oxidation. The peak eluting before this was estimated to be $p$-ABGlu ${ }_{6}$ from the known elution position of non-radioactive standards on this chromatographic system (Brown et al., I974). The peak eluting immediately after the main heptaglutamate peak was assumed to be the octaglutamate, although no standards were available to determine exactly where this derivative would elute.

This pattern, where folate heptaglutamate constituted 67 to $71 \%$ of the folate present with hexa- ( 12 to $16 \%$ ) and octo- ( 10 to $13 \%$ ) folate polyglutamates representing the remainder, was consistently found throughout the growth cycle of the organism, in samples taken on six occasions from $\mathrm{I}_{2}^{1}$ to $48 \mathrm{~h}$. No other folate polyglutamate was measureable in these experiments or in yeast cells that had entered the stationary phase. This pattern was consistent upon repetition on numerous occasions. Since the presence of a radioactive marker (Fig. I) makes accurate estimations of the peaks difficult these percentages were calculated for columns calibrated with non-radioactive markers. 


\section{DISCUSSION}

The strains of yeast used incorporated $p$-AB very well and formed it into long-chain folate polyglutamates of 6,7 and 8 glutamyl residues (Fig. I). Small amounts, up to $10 \%$, of radioactive $p-\mathrm{AB}$ were sometimes found after extraction. This could be because of a small pool of this precursor existing within the cell, or incomplete removal of the original medium during the washing procedure before extraction. The folate biosynthetic process thus rapidly elongates any newly-incorporated $p$ - $\mathrm{AB}$ to a long-chain polyglutamate with no intermediate shorter-chain compounds accumulating.

Little definitive information is available on the control of folate polyglutamate biosynthesis or the role of these additional glutamyl residues. On the basis of permeability studies in bacteria (McElwee \& Scott, 1973) and human marrow cells (Hoffbrand et al., 1973), it might be suggested that these biosynthetic processes are involved in storage of the vitamin simply by making its exit from the cell impossible. However, the complexity of the forms involved argues against such a role.

Folate or $p$-aminobenzoylpolyglutamates are difficult to synthesize chemically (Krumdieck \& Baugh, 1969). Their general lack of availability as markers for the co-chromatography used in the identification of folate polyglutamates from different sources, has limited research in this area to a small number of laboratories. Using the $p$-AB-requiring mutants described in this study, markers ideal for such chromatographic separation are easily available at high specific activity in high yield. The fact that three polyglutamates are isolated is an advantage since this serves to monitor the separation achieved.

We thank the Medical Research Council of Ireland and the Biomedical Trust who supported this work.

\section{REFERENCES}

Brown, J. P., Davidson, G. E. \& Scott, J. M. (1973). The identification of the forms of folate found in the liver, kidney and intestine of the monkey and their biosynthesis from exogenous pteroylglutamate (folic acid). Biochimica et biophysica acta 343, 78-88.

Brown, J. P., Dobbs, D., Davidson, G. E. \& Scott, J. M. (1974). Microbial synthesis of folate polyglutamates from labelled precursors. Journal of General Microbiology 84, 167-172.

Curthoys, N. P., Scott, J. M. \& Rabinowitz, J. C. (I972). Folate coenzymes of Clostridium acidi-urici. The isolation of $(l)-5$, IO-methenyltetrahydropteroyltriglutamate, its conversion to $(l)$-tetrahydropteroyl triglutamate and $(l)$-10-[14 $\mathrm{C}]$ formyltetrahydropteroyltriglutamate and the synthesis of $(l)$-Io-formyl-[6,7$\left.{ }^{3} \mathrm{H}_{2}\right]$ tetrahydropteroyltriglutamate and $(l)-6,7-\left[{ }^{3} \mathrm{H}_{2}\right]$ tetrahydropteroyltriglutamate. Journal of Biological Chemistry 247, 1959-1964.

Hoffrrand, A. V., Tripp, E., Houlihan, C. M. \& Scott, J. M. (1973). Studies on the uptake of synthetic conjugated folates by human bone marrow cells. Blood 42, I4 I-146.

Houlihan, C. M. \& SCOTT, J. M. (1972). The identification of pteroylpentaglutamate as the major folate derivative in rat liver and the demonstration of its biosynthesis from exogenous $\left[{ }^{3} \mathrm{H}\right]$ pteroylglutamate. Biochemical and Biophysical Research Communications 48, 1675-168I.

Kozloff, L. M. \& Lute, M. (I973). Bacteriophage tail components. IV. Pteroylpolyglutamate synthesis in $\mathrm{T}_{4}$ D-infected Escherichia coli B. Journal of Virology $\mathbf{1 1}, 630-636$.

Krumdieck, C. L. \& Baugh, C. M. (1969). The solid-phase synthesis of polyglutamates of folic acid. Biochemistry 8, 1568-1572.

McElwee, P. G. \& Scott, J. M. (1972). Folate metabolism in Streptococcus faecalis. BiochemicalJournal $\mathbf{1 2 7}$, $901-905$.

Pfiffner, J. J., Calkins, D. G., Bloom, E. S. \& O’Dell, B. L. (I946). On the peptide nature of vitamin Bc conjugate from yeast. Journal of the American Chemical Society 68, 1392.

Turner, J. C. (I969). Tritium counting with Triton X-Ioo scintillant. International Journal of Applied Radiation and Isotopes 20, 499-505. 